\title{
Anna Brzezińska-Rawa
}

Uniwersytet Mikołaja Kopernika, Torun

rawa@umk.pl

ORCID: https://orcid.org/0000-0003-3865-9823

\section{Dorota Sylwestrzak}

Uniwersytet Mikołaja Kopernika, Toruń

d_syl@law.uni.torun.pl

ORCID: https://orcid.org/0000-0003-4985-2880

\section{Administratywizacja prawa karnego w sprawach praktyk ograniczających konkurencję}

http://dx.doi.org/10.12775/SIT.2020.004

\section{Wprowadzenie}

W polskim systemie prawa konkurencja, jako wartość wysoko ceniona $^{1}$, podlega ochronie na płaszczyźnie prawa administracyjnego, cywilnego oraz karnego. Poddanie tego samego przedmiotu różnym metodom regulacji prowadzi do „wzajemnego przenikania się, przeplatania, a w konsekwencji do przemian ilościowych i jakościowych"2.

${ }^{1}$ A. Brzezińska-Rawa, Ochrona wartości wysoko cenionych $w$ działalności gospodarczej, w: Węzłowe problemy oddziaływania państwa na konkurencyjność $i$ innowacyjność gospodarki $z$ perspektywy różnych dziedzin prawa, red. A. Brzezińska-Rawa, D. Sylwestrzak, Toruń 2015, s. 11-23.

${ }^{2}$ H. Izdebski, Elementy teorii i filozofii prawa, Warszawa 2011, s. 241. 
Teza niniejszego opracowania brzmi, że prawo administracyjne wypiera, czy wręcz zastępuje prawo karne, czego dowodzi chociażby przykład sankcji o charakterze represyjnym nakładanych przez Prezesa Urzędu Ochrony Konkurencji i Konsumentów ${ }^{3}$ na podmioty stosujące praktyki ograniczające konkurencję (administracyjne kary pieniężne).

Zasadniczym celem niniejszego artykułu jest analiza wzajemnych relacji pomiędzy prawem karnym a prawem administracyjnym na przykładzie regulacji prawnych dotyczących spraw praktyk ograniczających konkurencję. Rozważania mają prowadzić w analizowanym przypadku do ustalenia, ile prawa karnego jest $\mathrm{w}$ prawie administracyjnym, czy występuje zjawisko wypierania prawa administracyjnego przez prawo karne bądź odwrotnie - to prawo administracyjne wypiera (zastępuje) prawo karne. Ocena wzajemnych relacji między prawem karnym a administracyjnym w analizowanym ujęciu zostanie dokonana na podstawie wybranych instytucji prawa materialnego oraz proceduralnych.

\section{Kryterium przedmiotu ochrony}

W prawie administracyjnym, w odróżnieniu od prawa karnego, przedmiotem ochrony jest konkurencja w ujęciu instytucjonalnym, chroniona $\mathrm{w}$ interesie publicznym ${ }^{4}$, którego wyrazem będzie utworzenie, utrzymanie albo przywrócenie konkurencji rozumianej jako mechanizm funkcjonowania rynku. Przedmiotem ochrony nie będzie konkurencja w ujęciu podmiotowym, chroniona w interesie prywatnym, chociaż pośrednio ochronie podlegać będą indywidualne interesy uczestników rynku (przedsiębiorców, konsumentów) oraz prawidłowość relacji zachodzących między nimi. Konkurencja

${ }^{3}$ Dalej: Prezes Urzędu, Prezes UOKiK.

${ }^{4}$ A. Brzezińska-Rawa, D. Sylwestrzak, The influence of the "important public interest” clause on the competitiveness of undertakings in Poland, „International Journal of Novel Research in Humanity and Social Sciences" 2017, Vol. 4, No. 6, s. 71-76; iidem, Constitutionally justified limitations of freedom of the economic activity: the case of Poland, „International Journal of Social Science and Humanities Research" 2017, Vol. 5, No. 4, s. 252-257. 
chroniona jest na gruncie prawa administracyjnego poprzez liczne zakazy i nakazy oraz obowiązki nakładane na jednostki. Zakazy, nakazy oraz obowiązki obwarowane są sankcjami administracyjnymi. Na gruncie ustawy o ochronie konkurencji i konsumentów ${ }^{5} \mathrm{za}$ delikty administracyjne przeciwko konkurencji uznano naruszenie zakazów praktyk ograniczających konkurencję w postaci porozumień ograniczających konkurencję (art. 6 u.o.k.k.), w zakresie niewyłączonym przez art. 7 i 8 u.o.k.k., jak również nadużywania pozycji dominującej ${ }^{6}$.

Uznanie zachowania za czyn zabroniony ${ }^{7}$ wymaga określenia czynu zabronionego oraz kar za ten czyn w akcie rangi ustawowej ${ }^{8}$, co stanowi wyraz realizacji zasady nullum crimen sine lege poenali anteriori wyrażonej w art. 42 ust. 1 Konstytucji RP ${ }^{9}$. Przepis ten

5 Tekst jednolity: Dz.U. z 2019 r. poz. 369 ze zm. (dalej: u.o.k.k.).

${ }^{6}$ Szerzej: A. Brzezińska-Rawa, Zakaz nadużycia pozycji dominujacej we wspólnotowym i polskim prawie antymonopolowym, Torun 2009; eadem, Dyskryminacja jako przejaw nadużycia pozycji dominujacej $w$ unijnym prawie konkurencji, „Państwo i Prawo” 2011, R. 66 z. 1, s. 83-93; eadem, Nadużycie pozycji dominujacej $w$ postaci stosowania ceny nadmiernie wygórowanej, „Przegląd Prawa Publicznego” 2011, nr 1, s. 70-79; eadem, Przesłanki oceny dyskryminacji cenowej jako przejawu nadużycia pozycji dominującej, „Przegląd Ustawodawstwa Gospodarczego" 2011, R. 64, nr 8, s. 9-14. Deliktami będą także niezgodne $z$ rynkiem wewnętrznym i zakazane wszelkie porozumienia między przedsiębiorstwami, wszelkie decyzje związków przedsiębiorstw i wszelkie praktyki uzgodnione, które mogą wpływać na handel między państwami członkowskimi i których celem lub skutkiem jest zapobieżenie, ograniczenie lub zakłócenie konkurencji wewnątrz rynku wewnętrznego (art. 101 TFUE). Traktat o funkcjonowaniu Unii Europejskiej z dnia 25 marca 1957 r. (Dz.U. z 2004 r. Nr 90, poz. 864 ze zm., dalej: TFUE).

7 Pod pojęciem kryminalizacji rozumiany jest zabieg ustawodawcy polegający na uznaniu określonego czynu za przestępstwo. Natomiast pojęcie penalizacji utożsamiane będzie $z$ ustanowieniem sankcji za określony czyn zabroniony. J. Kulesza, Problemy teorii kryminalizacji. Studium z zakresu prawa karnego i konstytucyjnego, Łódź 2017, s. 17 i n. L. Gardocki pojęciem kryminalizacji obejmuje uznanie jakiegoś czynu za przestępny, jak i utrzymywanie przestępności jakiegoś czynu, L. Gardocki, Zagadnienia teorii kryminalizacji, Warszawa 1990, s. 7.

${ }^{8}$ Wyrok SN z dnia 20 października 2009 r., III KK 247/09, Legalis nr 288300.

${ }^{9}$ Konstytucja Rzeczypospolitej Polskiej z dnia 2 kwietnia 1997 r. (Dz.U. Nr 78, poz. 483 ze zm., dalej: Konstytucja RP). 
dotyczy odpowiedzialności karnej. Na gruncie tego artykułu TK wielokrotnie wypowiadał się w zakresie odpowiedzialności karnoadministracyjnej, wskazując, że jest to „odpowiedzialność typu represyjno-porządkowego, będąca przejawem interwencjonizmu państwowego w sferach, jakie zostały uznane przez ustawodawcę za szczególnie istotne" 10 i gdzie „granica pomiędzy deliktem administracyjnym i będącą jego konsekwencją karą administracyjną a wykroczeniem jest płynna i określenie jej należy do zakresu swobody władzy ustawodawczej" ${ }^{11}$. TK uznał także za dopuszczalne funkcjonowanie w prawie administracyjnym kar pieniężnych, których nie można utożsamiać $\mathrm{z}$ grzywną ${ }^{12}$.

W polskim prawie zasadniczo porozumienia ograniczające konkurencję, odmiennie aniżeli w prawie amerykańskim ${ }^{13}$, nie stanowią przestępstwa, lecz są deliktem administracyjnym zagrożonym sankcją administracyjną. Na gruncie prawa karnego w ujęciu ścisłym, na zasadzie wyjątku, za przestępstwo uznawana jest zmowa przetargowa (art. $305 \S 2$ k.k.) ${ }^{14}$, przy czym należy podkreślić, że odpowiedzialność karna dotyczy naruszenia obowiązków określonych w prawie zamówień publicznych oraz przepisów o zwalczaniu nieuczciwej konkurencji. Pozostałe porozumienia nie są kryminalizowane ${ }^{15}$, są one deliktami administracyjnymi.

10 Por. wyroki TK z dnia: 10 grudnia 2007 r., P 43/07, „Orzecznictwo Trybunału Konstytucyjnego - Seria A” 2007, nr 11, poz. 155, 15 stycznia 2007 r., P 19/06, „Orzecznictwo Trybunału Konstytucyjnego - Seria A” 2007, nr 1, poz. 2.

${ }^{11}$ Wyrok TK z dnia 15 stycznia 2007 r., P 19/06, „Orzecznictwo Trybunału Konstytucyjnego - Seria A" 2007, nr 1, poz. 2.

12 Wyrok TK z dnia 29 kwietnia 1998 r., K 17/97, „Orzecznictwo Trybunału Konstytucyjnego” 1998, nr 3, poz. 30, „Glosa” 1999, nr 7, poz. 32.

${ }^{13}$ Szerzej na temat kryminalizacji prawa konkurencji P. Whelan, The criminalisation of European cartel enforcement: theoretical, legal and practical challenges, Oxford 2014.

${ }^{14}$ Ustawa $z$ dnia 6 czerwca 1997 r. - Kodeks karny (Tekst jednolity: Dz.U. z 2019 r. poz. 1950 ze zm., dalej: k.k.). Szerzej G. Materna, Zmowy przetargowe $w$ prawie ochrony konkurencji i prawie karnym, Warszawa 2016.

${ }_{15}$ Szerzej M. Król-Bogomilska, Zwalczanie karteli a prawo do rzetelnego procesu i prawo do prywatności-sporne zagadnienia, w: Prawo konkurencji. 25 lat, red. T. Skoczny, Warszawa 2015, LEX; eadem, Zwalczanie karteli $w$ prawie 


\section{Kryterium podmiotowe}

W sprawach praktyk ograniczających konkurencję przedmiotem analizy będą stosunki zewnętrzne - prawnie określone uprawnienia i obowiązki podmiotów biorących udział w postępowaniu w sprawach praktyk ograniczających konkurencję ${ }^{16}$, tj. Prezesa Urzędu, stron postępowania, uczestników postępowania. Prezes Urzędu nie jest organem sądowym sprawującym wymiar sprawiedliwości ${ }^{17}$, jest centralnym organem administracji rządowej. Odpowiedzialność administracyjnoprawną za delikty administracyjne ponosi co do zasady przedsiębiorca (zdefiniowany w szerokim ujęciu) naruszający ustawowe zakazy ${ }^{18}$. Należy zauważyć, że wskutek nowelizacji u.o.k.k. z 2014 r. rozszerzono zakres podmiotowy odpowiedzialności administracyjnoprawnej za delikty administracyjne o osoby zarządzające (art. 6a u.k.k.) ${ }^{19}$, tj. osoby kierujące przedsiębiorstwem, w szczególności pełniące funkcję kierowniczą lub wchodzące

antymonopolowym i karnym, Warszawa 2013; D. Danecka, Konwersja odpowiedzialności karnej $w$ administracyjna $w$ prawie polskim, Warszawa 2018, LEX; A. Jurkowska-Gomułka, Publiczne i prywatne egzekwowanie zakazów praktyk ograniczajacych konkurencję, Warszawa 2013.

${ }^{16}$ Szerzej D. Sylwestrzak, Postępowanie przed Prezesem Urzędu Ochrony Konkurencji i Konsumentów, „Przegląd Ustawodawstwa Gospodarczego” 2002, R. 55, nr 9, s. 16-23.

17 Szerzej: A. Brzezińska-Rawa, D. Sylwestrzak, Instytucjonalne uwarunkowania działalności gospodarczej niezależne od rodzaju działalności gospodarczej, w: Rola państwa $w$ procesach podnoszenia konkurencyjności i innowacyjności przedsiębiorstw. Diagnoza istniejacych uwarunkowań $i$ barier prawnych, perspektywy rozwoju, red. A. Brzezińska-Rawa, Warszawa 2015, s. 9-17.

18 Podmiotem odpowiedzialnym będzie osoba fizyczna, osoba prawna, ale także jednostka organizacyjna niemająca osobowości prawnej, której ustawa przyznaje zdolność prawną, organizująca lub świadcząca usługi o charakterze użyteczności publicznej, które nie są działalnością gospodarczą w rozumieniu przepisów Ustawy z dnia 6 marca 2018 r. - Prawo przedsiębiorców (art. 4 pkt 1 lit. a u.o.k.k.).

19 Ustawa z 10 czerwca 2014 r. o zmianie ustawy o ochronie konkurencji i konsumentów oraz ustawy - Kodeks postępowania cywilnego, Dz.U. z 2014 r. poz. 945. 
w skład organu zarządzającego przedsiębiorcy ${ }^{20}$. Odpowiedzialność administracyjnoprawna osób zarządzających jest ograniczona do przypadków porozumień ograniczających konkurencję, innych niż tzw. zmowa przetargowa ${ }^{21}$. Ponadto nie dotyczy ona naruszenia zakazu nadużycia pozycji dominującej przez przedsiębiorcę zajmującego taką pozycję na rynku właściwym ${ }^{22}$. Dyskusyjne jest to, czy osobą zarządzającą $\mathrm{w}$ rozumieniu art. 4 pkt 3a u.o.k.k. może być tylko osoba fizyczna ${ }^{23}$, czy także podmiot zbiorowy, np. spółka $z$ ograniczoną odpowiedzialnością będąca komplementariuszem w spółce komandytowej lub spółce komandytowo-akcyj$n^{24}$. Osoba zarządzająca odpowiada tylko wówczas, gdy umyślnie dopuści swoimi działaniami lub zaniechaniami do naruszenia

${ }^{20}$ Przebieg procesu legislacyjnego opisują: A. Piszcz, „Osoba zarzadzająca” $w$ rządowym projekcie ustawy zmieniającej ustawę o ochronie konkurencji i konsumentów, „Internetowy Kwartalnik Antymonopolowy i Regulacyjny” 2013, nr 7(3), s. 23-30; S. Syp, O odpowiedzialności osób fizycznych w polskim prawie konkurencji - de lege lata i de lege ferenda, „Internetowy Kwartalnik Antymonopolowy i Regulacyjny" 2012, nr 4(1), s. 7-19; D. Wolski, Uwagi dotyczace wybranych instytucji $w$ projekcie nowelizacji ustawy o ochronie konkurencji i konsumentów, „Internetowy Kwartalnik Antymonopolowy i Regulacyjny” 2013, nr 7(2), s. 16-22.

${ }^{21}$ A. Piszcz, w: Ustawa o ochronie konkurencji i konsumentów, Komentarz, red. T. Skoczny, Warszawa 2014, s. 115.

${ }^{22}$ P. Dolniak-Mądrzycka, Odpowiedzialność osób zarzadzających przedsiębiorca $w$ świetle nowelizacji ustawy o ochronie konkurencji i konsumentów, „Kwartalnik Krajowej Szkoły Sądownictwa i Prokuratury” 2016, nr 2(22), s. 29; A. Maziarz, Kilka uwag do projektu nowelizacji ustawy o ochronie konkurencji i konsumentów, „Internetowy Kwartalnik Antymonopolowy i Regulacyjny” 2013, nr 7(2), s. 10.

${ }^{23}$ K. Kohutek, w: Ustawa o ochronie konkurencji i konsumentów. Komentarz, red. K. Kohutek, M. Sieradzka, wyd. 2, Warszawa 2014, s. 139; M. Materna, A. Zawłocka-Turno, Materialne i procesowe zmiany $w$ zakresie praktyk ograniczających konkurencję i naruszających zbiorowe interesy konsumentów, „Internetowy Kwartalnik Antymonopolowy i Regulacyjny” 2015, nr 2(4), s. 16.

${ }^{24}$ Tak: A. Piszcz, w: Ustawa o ochronie, s. 115; eadem, Sankcje w polskim prawie antymonopolowym, Białystok 2013, s. 347; P. Korycińska-Rządca, Odpowiedzialność osoby fizycznej $w$ zwiazku z zawarciem przez przedsiębiorce porozumienia przetargowego $w$ prawie ochrony konkurencji $i w$ prawie karnym, „Internetowy Kwartalnik Antymonopolowy i Regulacyjny” 2017, nr 1(6), s. 111 . 
prawa $^{25}$. Sankcją o charakterze administracyjnym jest stwierdzenie tego, że osoba zarządzająca dopuściła do naruszenia przez przedsiębiorcę zakazów, natomiast sankcja administracyjno-karna w postaci kary pieniężnej jest wobec niej komplementarna ${ }^{26}$. Obowiązek dowodu w powyższym zakresie będzie spoczywał na Prezesie Urzędu ${ }^{27}$.

\section{Kryterium sankcji}

Problematyka sankcji w prawie administracyjnym stanowiła i nadal stanowi przedmiot ożywionej dyskusji zarówno w nauce prawa administracyjnego ${ }^{28}$, jak i prawie konkurencji ${ }^{29}$ oraz orzecznic-

25 B. Kasztelan-Świetlik, Nowelizacja ustawy antymonopolowej. Wystapienie Wiceprezes UOKiK, Bernadety Kasztelan-Świetlik, „Internetowy Kwartalnik Antymonopolowy i Regulacyjny” 2015, nr 2(4), s. 9.

${ }^{26}$ M. Materna, A. Zawłocka-Turno, Materialne i procesowe, s. 16.

27 B. Kasztelan-Świetlik, Nowelizacja ustawy, s. 9.

${ }^{28}$ J. Jendrośka, Koncepcja sankcji karnej $w$ prawie administracyjnym, w: Zbiór studiów z zakresu nauk administracyjnych, red. Z. Rybicki, M. Gromadzka-Grzegorzewska, M. Wyrzykowski, Wrocław 1978, s. 123 i n.; F. Longchamps, Problemy pogranicza prawa administracyjnego, „Studia Prawnicze” 1967, z. 16, s. 12 i n.; J. Zimmermann, Aksjomaty prawa administracyjnego, Warszawa 2013, LEX; M. Wincenciak, Sankcje $w$ prawie administracyjnym i procedura ich wymierzania, Warszawa 2008, LEX; D.K. Nowicki, S. Peszkowski, Kilka uwag o szczególnym charakterze administracyjnych kar pieniężnych, w: Administracyjne kary pieniężne $w$ demokratycznym państwie prawa, red. M. Błachucki, Warszawa 2015, s. 11-27. Szerzej: A. Wróbel, Odpowiedzialność administracyjna $w$ orzecznictwie Trybunału Konstytucyjnego (na przykładzie administracyjnych kar pieniężnych), „Europejski Przegląd Sądowy” 2014, nr 9, s. 33 i n.; M. Wyrzykowski, M. Ziółkowski, Konstytucyjny status proceduralny jednostki jako adresata działań organów administracji, w: Konstytucyjne podstawy funkcjonowania administracji publicznej. System prawa administracyjnego, red. R. Hauser, Z. Niewiadomski, A. Wróbel, t. 2, Warszawa 2012.

${ }^{29}$ M. Modzelewska de Raad, System kar pieniężnych $w$ polskiej ustawie o ochronie konkurencji i konsumentów - potrzeba i kierunek dalszych zmian, „Internetowy Kwartalnik Antymonopolowy i Regulacyjny" 2015, nr 2(4), s. 93 i n.; M. Król-Bogomilska, Kary pieniężne $w$ prawie antymonopolowym ( $w$ ustawie o ochronie konkurencji i konsumentów, $w$ europejskim prawie wspólnotowym), Warszawa 2001; M. Sachajko, Istota i charakter prawny antymonopolowych kar pieniężnych, „Ruch Prawniczy, Ekonomiczny i Socjologiczny” 2002, R. LXVI, 
twie $^{30}$. Jak słusznie zauważa Jan Zimmermann, sankcje (kary) administracyjne powinny być stosowane „za naruszenie materialnych norm prawa administracyjnego" ${ }^{31}$. Naruszenie publicznego prawa konkurencji (popełnienie deliktu administracyjnego) jest zagrożone sankcjami o charakterze administracyjnym ${ }^{32}$. Przyjmuje się, że kara administracyjna jako środek represji powinna pełnić funkcję „zabezpieczenia przed takimi naruszeniami prawa, gdzie stosowanie innych środków przymusu jest nieaktualne oraz gdy nie można już zmienić stanu faktycznego, zaistniałego przez naruszenie nakazu lub zakazu"33.

Prezes UOKiK został wyposażony w kompetencję do nakładania na przedsiębiorcę stosującego zakazane praktyki kar pieniężnych w drodze decyzji ${ }^{34}$. Ustalając wymiar kar, Prezes Urzędu zobowią-

z. 1, s. 57 i n.; D. Sylwestrzak, Postępowanie przed Prezesem Urzędu Ochrony Konkurencji i Konsumentów, Warszawa 2012, s. 78-86; M. Bernatt, Tailor-made rules needed: a balance approach to imposition of administrative sanctions in Poland, „Jean Monet Working Paper” 2014, nr 22/14, https://jeanmonnetprogram.org/wp-content/uploads/2014/12/JMWP22bernatt.pdf; idem, Sprawiedliwość proceduralna $w$ postępowaniu przed organem ochrony konkurencji, Warszawa 2011; A. Doniec, Stosowanie kar pieniężnych w unijnym i polskim prawie konkurencji $w$ świetle wymogów ochrony praw człowieka, Warszawa 2016.

${ }^{30}$ Por. wyroki TK z dnia: 15 stycznia 2007 r., P 19/06, „Orzecznictwo Trybunału Konstytucyjnego. Zbiór Urzędowy” 2007, nr 1A, poz. 2; 5 maja 2009 r., P 64/07, „Orzecznictwo Trybunału Konstytucyjnego. Zbiór Urzędowy” 2009, nr 5A, poz. 64, 18 kwietnia 2000 r., K 23/99, „Orzecznictwo Trybunału Konstytucyjnego, Zbiór Urzędowy” 2000, nr 3, poz. 89.

31 J. Zimmermann, Prawo administracyjne, Warszawa 2018, s. 111.

${ }^{32}$ L. Staniszewska, Kodyfikacja administracyjnej kary pieniężnej jako instrumentu prawnego na styku $z$ odpowiedzialnościa karna, w: Prawo administracyjne dziś i jutro, red. J. Lang, M. Wierzbowski, Warszawa 2018, s. 199 i n.

33 J. Jendrośka, Koncepcja, s. 134.

${ }^{34} \mathrm{Z}$ tytułu naruszenia przepisów prawa materialnego, tj. naruszenia zakazu z art. 6 i 9 u.o.k.k. oraz art. 101 TFUE, Prezes Urzędu może nałożyć na przedsiębiorcę karę pieniężną w wysokości nie większej niż 10\% obrotu osiągniętego w roku obrotowym poprzedzającym rok nałożenia kary, jeżeli przedsiębiorca ten, choćby nieumyślnie, popełnił delikt administracyjny (art. 106 ust. 1 pkt 1-2 u.o.k.k.). Stosownie do art. 106a ust. 1 u.o.k.k. Prezes Urzędu może nałożyć na osobę zarządzającą karę pieniężną w wysokości do $2 \mathrm{mln}$ zł, jeżeli osoba ta umyślnie dopuściła do naruszenia przez przedsiębiorcę zakazów 
zany jest do uwzględnienia kryteriów jej wymierzania określonych w art. 111 u.o.k.k. Można wyróżnić kryteria wspólne, takie jak okoliczności naruszenia przepisów ustawy oraz uprzednie naruszenie przepisów ustawy. Pozostałe kryteria różnią się w zależności od rodzaju nakładanej kary, należy do nich zaliczyć: okres, stopień oraz skutki rynkowe naruszenia przepisów ustawy; stopień wpływu zachowania osoby zarządzającej na naruszenie, którego dokonał przedsiębiorca; przychody uzyskane przez osobę zarządzającą u danego przedsiębiorcy; wpływ naruszenia na przebieg i termin zakończenia postępowania; skutki rynkowe niewykonania decyzji, postanowień lub wyroków. Przy nakładaniu kar organ administracyjny uwzględnia także okoliczności łagodzące oraz obciążające (art. 111 ust. 2 u.o.k.k.) ${ }^{35}$.

określonych w art. 6 ust. 1 pkt 1-6 ustawy lub w art. 101 ust. 1 lit. a-e TFUE. Ponadto ustawodawca przewidział możliwość nakładania kar z tytułu naruszenia przepisów proceduralnych (art. 106 ust. 2 u.o.k.k.) oraz niewykonania orzeczeń (art. 107 i 108 ust. 1 pkt 1 u.o.k.k.).

35 Do okoliczności łagodzących w sprawach naruszenia zakazu praktyk ograniczających konkurencję ustawodawca zaliczył: dobrowolne usunięcie skutków naruszenia, zaniechanie stosowania zakazanej praktyki przed wszczęciem postępowania lub niezwłocznie po jego wszczęciu, podjęcie $z$ własnej inicjatywy działań w celu zaprzestania naruszenia lub usunięcia jego skutków, współpracę z Prezesem Urzędu w toku postępowania, w szczególności przyczynienie się do szybkiego i sprawnego przeprowadzenia postępowania, bierną rolę przedsiębiorcy w naruszeniu zakazu porozumień ograniczających konkurencję, w tym unikanie przez niego wprowadzenia w życie postanowień porozumienia ograniczającego konkurencję, działanie pod przymusem - w przypadku naruszenia zakazu porozumień ograniczających konkurencję (art. 111 ust. 3 pkt 1 u.o.k.k.). Z kolei do okoliczności obciążających w sprawach praktyk ograniczających konkurencję zaliczono: odgrywanie roli lidera lub inicjatora porozumienia ograniczającego konkurencję lub nakłanianie innych przedsiębiorców do uczestnictwa w porozumieniu - w przypadku naruszenia zakazu porozumień ograniczających konkurencję, przymuszanie, wywieranie presji lub stosowanie środków odwetowych w stosunku do innych przedsiębiorców lub osób w celu wprowadzenia w życie lub kontynuowania naruszenia, dokonanie uprzednio podobnego naruszenia, umyślność naruszenia (art. 111 ust. 4 pkt 1 u.o.k.k.). Szerzej: A. Piszcz, Nowe elementy regulacji prawnej kar pieniężnych $w$ ustawie o ochronie konkurencji i konsumentów, „Internetowy Kwartalnik Antymonopolowy i Regulacyjny” 2015, nr 2(4), s. 42-58; A. Maziarz, Kilka uwag do projektu, s. 12-13. 
W świetle powyższego powstaje pytanie o charakter prawny kar wymierzanych przez Prezesa UOKiK, ponieważ niewątpliwie w niektórych przypadkach kary te będą zdecydowanie bardziej dolegliwe aniżeli sankcje karne przewidziane w prawie karnym. Czy należy je utożsamiać $z$ sankcjami karnymi? W orzecznictwie sądowym przyjęto, że kary wymierzane przez Prezesa Urzędu mają charakter kar administracyjnych ${ }^{36}$. Należy podkreślić, że zasadniczym celem kar pieniężnych jest zapewnienie skuteczności zakazów praktyk ograniczających konkurencję oraz realizacja celów ustawy o ochronie konkurencji i konsumentów. Podkreśla się, że funkcja kar wymierzanych za naruszenie zakazanych praktyk „nie ogranicza się jednak tylko do prewencji, czyli zapobiegania kolejnym naruszeniom ustawy przez tego samego przedsiębiorcę (prewencja szczególna) oraz odstraszania od dopuszczania się tych naruszeń w przyszłości przez innych przedsiębiorców (prewencja ogólna). Kary te pełnią funkcje represyjne, jak również funkcje egzekucyjne (przymuszające do wykonania)" 37 .

W nauce prawa administracyjnego zwraca się uwagę, że „administracyjna kara pieniężna oraz kara grzywny za przestępstwo, pomimo podobieństw w zakresie funkcji represyjnej oraz prewencyjnej, różnią się podstawami aksjologicznymi, ponieważ administracyjna kara pieniężna wymierzana jest $\mathrm{z}$ tytułu naruszenia norm prawa administracyjnego, natomiast kara grzywny wymierzana jest $z$ tytułu zachowania niezgodnego $z$ normą prawną"38. Przyjmuje się, że sankcje administracyjne pełnią funkcje „represyjne, dyscyplinujące, prewencyjne, wychowawcze, przymuszające, odszkodowawcze, restytucyjne, konserwatorskie (np. w sferze ochrony środowiska), redystrybucyjne lub stabilizacyjne" ${ }^{39}$. Dotychczas w nauce prawa administracyjnego wskazywano, że odpowiedzialność administra-

${ }^{36}$ Wyrok SN z dnia 14 kwietnia 2010 r., III SK 1/10, Legalis nr 385429.

37 Wyrok SO w Warszawie $z$ dnia 13 marca 2018 r., XVII AmA 34/17, Legalis $\mathrm{nr} 1783078$.

${ }^{38}$ L. Staniszewska, Kodyfikacja, s. 199-200.

${ }^{39}$ M. Stahl, Sankcje administracyjne - problemy węzłowe, w: Sankcje administracyjne. Blaski i cienie, red. M. Stahl, R. Lewicka, M. Lewicki, Warszawa 2011 , s. 27. 
cyjna ma charakter odpowiedzialności obiektywnej, bowiem jej podstawą był sam fakt naruszenia przepisów prawa administracyjnego ${ }^{40}$.

\section{Kryterium przepisy proceduralne}

Na gruncie przepisów proceduralnych normujących postępowanie w sprawach praktyk ograniczających konkurencję możemy dostrzec inkorporowanie do procedury administracyjnej instytucji charakterystycznych dla postępowania karnego. Postępowanie w sprawach praktyk ograniczających konkurencję jest postępowaniem administracyjnym, kwalifikowanym jako postępowanie szczególne ${ }^{41}$, wyspecjalizowane ${ }^{42}$ czy też hybrydowe ${ }^{43}$.

Przejawem wypierania prawa karnego przez prawo administracyjne jest konstrukcja odesłania do stosowania kodeksu postępowania karnego w zakresie przeszukania pomieszczeń i rzeczy (art. 91 ust. 4, art. 105q pkt 3 u.o.k.k.). Regulacje zawarte w u.o.k.k. nie zawierają stosownych gwarancji procesowych dla podmiotów poddanych kontroli i przeszukaniu. W wyroku z 16 stycznia 2019 r. Trybunał Konstytucyjny orzekł o niezgodności art. 105n ust. 4 zdanie drugie u.o.k.k. $\mathrm{z}$ art. $78 \mathrm{w}$ zw. $\mathrm{z}$ art. 45 ust. 1 Konstytucji $\mathrm{RP}^{44}$. Przepis ten wykluczał bowiem możliwość zaskarżenia po-

${ }^{40}$ M. Wincenciak, Przesłanki wyłaczajace wymierzenie sankcji administracyjnej, w: Sankcje administracyjne. Blaski i cienie, red. M. Stahl, R. Lewicka, M. Lewicki, Warszawa 2011, s. 605. Szerzej M. Wincenciak, Sankcje, LEX.

${ }^{41}$ D. Sylwestrzak, Postępowanie, s. 296.

${ }^{42}$ M. Gajda-Durlik, Dekodyfikacja postępowania administracyjnego, w: Koncepcja systemu prawa administracyjnego, red. J. Zimmermann, Warszawa 2007, s. 202.

${ }^{43}$ Z. Kmieciak, Postępowanie $w$ sprawach ochrony konkurencji a koncepcja procedury hybrydowej, „Państwo i Prawo” 2002, nr 4, s. 31 i n.; K. Róziewicz-Ładoń, Postępowanie przed Prezesem Urzędu Ochrony Konkurencji i Konsumentów $w$ zakresie przeciwdziałania praktykom ograniczajacym konkurencję, Warszawa 2011, s. 449.

${ }^{44}$ Wyrok TK z dnia 16 stycznia 2019 r., P 17/19, Legalis nr 1861230. Trybunał Konstytucyjny, Komunikat prasowy w sprawie P 19/17, http:// trybunal.gov.pl/postepowanie-i-orzeczenia/komunikaty-prasowe/komuni- 
stanowienia wydanego w przedmiocie wyrażenia przez sąd zgody na przeprowadzenie przeszukania pomieszczeń i rzeczy w postępowaniu wyjaśniającym i w postępowaniu głównym. Ze względu na daleko idącą ingerencję w sferę praw przedsiębiorcy w postaci naruszenia swobody działalności gospodarczej oraz prawa do prywatności, prawa własności w stopniu większym, niż to ma miejsce w przypadku zwykłej kontroli, TK stwierdził, że „w toku przeszukania powinny znaleźć zastosowanie standardy przewidziane dla procedury karnej, w zakresie ochrony praw przeszukiwanego lub też innych osób, których prawa mogą być naruszone w wyniku przeszukania" ${ }^{45}$.

Ustawodawca zdecydował się ponadto na recypowanie charakterystycznych instytucji dla procesu karnego na grunt postępowania administracyjnego. Przykładem może być instytucja dobrowolnego poddania się karze uregulowana w art. 89a u.o.k.k. ${ }^{46}$ czy też instytucja leniency (art. 113a-k u.o.k.k.) ${ }^{47}$ wzorowana na instytucji świadka koronnego ${ }^{48}$. Pomimo przejęcia wielu instytucji $z$ prawa karnego do postępowania administracyjnego ustawodawca nie zdecydował się na przyznanie Prezesowi Urzędu uprawnień oskarżyciela publicznego w sprawach zmów przetargowych.

katy-po/art/10461-ustawa-o-ochronie-konkurencji-i-konsumentow/ (dostęp: 24.01.2019 r.).

45 Trybunał Konstytucyjny, Komunikat prasowy w sprawie P 19/17, http:// trybunal.gov.pl/postepowanie-i-orzeczenia/komunikaty-prasowe/komunikaty-po/art/10461-ustawa-o-ochronie-konkurencji-i-konsumentow/, (dostęp: 24.01.2019 r.).

${ }^{46}$ Szerzej A. Brzezińska-Rawa, D. Sylwestrzak, Settlement $w$ postępowaniach $w$ sprawach praktyk ograniczajacych konkurencję - instytucja skutecznej ochrony konkurencji czy narzędzie ułatwiajace działalność organu antymonopolowego?, w: 25 lat fundamentów wolności działalności gospodarczej. Tendencje rozwojowe, red. J. Grabowski, K. Pokryszka, A. Hołda-Wydrzyńska, Katowice 2013, s. 114-126.

${ }^{47}$ Szerzej A. Brzezińska-Rawa, D. Sylwestrzak, Leniency $w$ sprawach porozumień ograniczajacych konkurencję $w$ Polsce. Przeszłość, teraźniejszość, przyszłość, w: Dziesięć lat polskich doświadczeń w Unii Europejskiej. Problemy administracyjnoprawne, red. J. Sługocki, t. I, Szczecin 2014, s. 221-236.

${ }^{48}$ R. Molski, w: Ustawa o ochronie konkurencji i konsumentów. Komentarz, red. T. Skoczny, Warszawa 2014, s. 1402. 


\section{Dyskusja}

Istotny wpływ na rozwiązania prawne przyjęte w polskim prawie miało prawo UE, które nie objęło prawa karnego, a przewidywało stosowanie surowych sankcji w stosunku do podmiotów, które popełniały najcięższe przewinienia naruszające reguły konkurencji w trybie administracyjnym. W doktrynie prezentowane są także poglądy o represji administracyjnej za delikty administracyjne jako standardzie wprowadzonym przez prawo unijne ${ }^{49}$ oraz zastępowaniu odpowiedzialności karnej przez administracyjną ${ }^{50}$.

\subsection{Czy delikty administracyjne są jednocześnie przestępstwami?}

Zasadniczo odpowiedzialność karna różni się od odpowiedzialności administracyjnej przede wszystkim tym, że w prawie karnym oparta jest ona na zasadzie winy i cechuje ją represyjność, natomiast odpowiedzialność administracyjna ma charakter obiektywny i represyjność nie jest jej zasadniczym celem ${ }^{51}$. Mając na uwadze

49 T. Oczkowski, Komentarz do art. 30 rozporzadzenia UE Nr 596/2014 w sprawie nadużyć na rynku, w: Rozporządzenie UE Nr 596/2014 w sprawie nadużyć na rynku. Prawo rynku kapitałowego. Komentarz, red. M. Wierzbowski, Warszawa 2016, Legalis.

${ }^{50}$ Szerzej D. Danecka, Konwersja odpowiedzialności karnej $w$ administracyjna $w$ prawie polskim, Warszawa 2018, LEX; W. Radecki, Kilka uwag o zastępowaniu odpowiedzialności karnej odpowiedzialnością administracyjna, w: Wspótczesne problemy nauk penalnych, „Acta Universitatis Wratislaviensis” nr 1663, Wrocław 1994, s. 13-22; T. Oczkowski, Delikty administracyjne jako szczególna forma represji publicznej. Próba określenia przyczyn coraz większego znaczenia sankcji administracyjnych, w: Teoretyczne i praktyczne problemy wspótczesnego prawa karnego. Materiały z konferencji naukowej. Lublin, 26-27 września 2011, red. T. Bojarski, A. Michalska-Warias, I. Nowikowski, K. Nazar-Gutowska, J. Piórkowska-Flieger, D. Firkowski, Lublin 2011, s. 173-186.

${ }^{51}$ W. Lang, Struktura odpowiedzialności prawnej (Studium analityczne z dziedziny teorii prawa), „Zeszyty Naukowe Uniwersytetu Mikołaja Kopernika w Toruniu. Nauki Humanistyczno-Społeczne” 1968, nr 31, s. 36-38. 
obowiązujące regulacje prawne, należy stwierdzić, że delikty administracyjne - zakazane praktyki ograniczające konkurencję uregulowane na gruncie ustawy o ochronie konkurencji i konsumentów nie są jednocześnie czynami zabronionymi w rozumieniu prawa karnego $\mathrm{z}$ wyjątkiem zmowy przetargowej. Odpowiedzialność za naruszenie zakazu praktyk ograniczających konkurencję ma charakter odpowiedzialności administracyjnej, obiektywnej, zagrożonej sankcjami administracyjnymi, której zasadniczym celem nie jest represja. Odpowiedzialność za delikty administracyjne przeciwko konkurencji, mimo iż ma charakter subiektywny ${ }^{52}$, z woli ustawodawcy nadal ma charakter obligatoryjnej represyjnej odpowiedzialności administracyjnej. W tym zakresie aktualizuje się koncepcja sankcji karnej w prawie administracyjnym ${ }^{53}$.

\subsection{Czy odpowiedzialność mogą ponosić podmioty zbiorowe?}

Z punktu widzenia odpowiedzialności administracyjnej mającej charakter odpowiedzialności obiektywnej za stwierdzony delikt administracyjny nie ma żadnych ograniczeń w zakresie stosowania sankcji administracyjnych również wobec tzw. podmiotów zbiorowych ${ }^{54}$.

\subsection{Jaki charakter mają sankcje nakładane przez Prezesa Urzędu?}

W związku z wprowadzeniem obowiązku uwzględniania przez Prezesa Urzędu okoliczności łagodzących i obciążających w postaci

${ }^{52}$ M. Namysłowska, w: Ustawa o zmianie ustawy o ochronie konkurencji i konsumentów z 5.8.2015 r. Komentarz, red. M. Namysłowska, A. Piszcz, Warszawa 2016, Legalis.

${ }^{53}$ J. Jendrośka, Koncepcja, s. 123 i n.; D. Szumiło-Kulczycka, Prawo administracyjno-karne, Kraków 2004.

${ }^{54}$ Ustawa $z$ dnia 28 października 2002 r. o odpowiedzialności podmiotów zbiorowych za czyny zabronione pod groźbą kary (tekst jednolity: Dz.U. z 2020 r. 
umyślności lub nieumyślności naruszenia budzi szereg wątpliwości, czy kary te są nadal karami administracyjnymi. W ocenie autorek więcej argumentów przemawia na rzecz tezy, że delikty administracyjne w postaci naruszenia zakazanych praktyk ograniczających konkurencję poddane zostały represyjnym sankcjom administracyjnym wymierzanym przez organ administracji publicznej w postępowaniu administracyjnym ${ }^{55}$. Wysokość kar wymierzanych przez Prezesa Urzędu oraz determinanty ich wymierzania (art. 111 u.o.k.k.) rodzi dyskusję co do ich charakteru. $Z$ całą pewnością obecnie odpowiedzialność za delikty administracyjne w analizowanym zakresie ma charakter subiektywny, a nie obiektywny.

\subsection{Czy obowiązujące gwarancje procesowe chronią przedsiębiorców?}

Obowiązująca regulacja wywołuje zastrzeżenia $\mathrm{z}$ punktu widzenia gwarancji procesowych. Jedną $z$ podstawowych zasad $w$ procesie karnym jest zasada nullum crimen sine culpa, a podstawę wymiaru kary stanowi wina sprawcy. W procesie karnym oskarżony/obwiniony nie musi składać wyjaśnień, dowodzić swojej niewinności. Zupełnie inne reguły dowodzenia obowiązują w postępowaniu przed Prezesem UOKiK, gdy ciężar dowodzenia spoczywa na przedsiębiorcy, który musi udowodnić, że nie stosuje bądź nie stosował zakazanych praktyk ograniczających konkurencję. $Z$ punktu widzenia procesowego prawa dostrzegalna jest tendencja do wprowadzania licznych instytucji z procesu karnego do administracyjnego postępowania w sprawach praktyk ograniczających konkurencję bez zapewnienia jednostkom stosownych gwarancji procesowych charakterystycznych dla procesu karnego, przede wszystkim zasady domniemania niewinności czy też prawa do obrony ${ }^{56}$. Sze-

poz. 358); T. Oczkowski, Komentarz do art. 30 rozporządzenia UE Nr 596/2014 $w$ sprawie nadużyć na rynku, w: Rozporzadzenie UE Nr 596/2014 w sprawie nadużyć na rynku, Legalis.

55 Tak też T. Oczkowski, Komentarz, Legalis.

${ }^{56}$ Zob. M. Król-Bogomilska, Zwalczanie karteli, LEX. 
rokie uprawnienia Prezesa UOKiK w zakresie metod i środków pozyskiwania dowodów dają podstawę do wyciągnięcia wniosku, że Prezes Urzędu został wyposażony w narzędzia charakterystyczne dla organów ścigania.

\section{Podsumowanie}

Pomimo odrębności i niezależności obu gałęzi prawa należy zauważyć, że nie da się określić jednoznacznych kryteriów, które pozwolą na ich rozdzielenie. W sprawach porozumień ograniczających konkurencję prawo karne i prawo administracyjne pełnią wobec siebie rolę komplementarną (uzupełniająca). Rozstrzygnięcia wydane w sprawach karnych oraz decyzje administracyjne stanowią prejudykat do zastosowania prawa karnego bądź administracyjnego. $Z$ całą pewnością normy publicznoprawne ochrony konkurencji mogą być egzekwowane w drodze karnej, podmioty pokrzywdzone w wyniku naruszenia zakazanych praktyk mogą inicjować postępowania karne w zakresie przewidzianym przez te przepisy. Należy podkreślić, że pokrzywdzony ma możliwość zainicjowania działań organu antymonopolowego poprzez złożenie zawiadomienia o podejrzeniu stosowania zakazanych praktyk, może także dochodzić swoich praw w postępowaniu karnym przed sądem powszechnym.

Istotne znaczenie ma $\mathrm{z}$ jednej strony zapewnienie skutecznych instrumentów zapewniających ochronę konkurencji jako dobra wspólnego, a $z$ drugiej strony zapewnienie skutecznych instrumentów dochodzenia naruszonych interesów uprawnionych jednostek. Mając na uwadze analizowane instytucje, należy przyjąć, że proces wypierania prawa karnego przez prawo administracyjne w sprawach praktyk ograniczających konkurencję jest widoczny w szczególności w odniesieniu do sankcji oraz postępowania przed Prezesem Urzędu. Mamy tutaj do czynienia ze zjawiskiem administratywizacji prawa karnego, w którym organ administracji publicznej $z$ woli ustawodawcy polskiego i unijnego stosuje instrumenty prawa represyjnego. Przegląd sankcji administracyjnych w analizowanych sprawach prowadzi do konkluzji, że zdecydowanie bardziej dolegliwe wydają się sankcje przewidziane w prawie administracyjnym. Stoso- 
wanie środków represji w trybie administracyjnym daje skuteczne narzędzie w zwalczaniu niekorzystnych zjawisk rynkowych, wynika to po części z tego, że odpowiedzialność administracyjna ma charakter obiektywny, a ponadto $\mathrm{w}$ trybie administracyjnym istnieje możliwość nałożenia sankcji np. na podmioty zbiorowe.

W doktrynie zwraca się uwagę na tendencje ustawodawcy do przenoszenia wykroczeń do prawa administracyjnego zagrożonych sankcjami administracyjnymi ${ }^{57}$. W orzecznictwie ETPC postępowanie administracyjne, które może zostać zakończone nałożeniem dolegliwej kary, jest kwalifikowane jako postępowanie karne ${ }^{58}$, a skoro tak, to wydaje się, że zasadne byłoby stworzenie także właściwych gwarancji procesowych charakterystycznych dla procedury karnej, m.in. w zakresie domniemania niewinności, prawa do obrony, reguł ciężaru dowodzenia, prawa do sądu itd.

Podsumowując, należy stwierdzić, że ochrona konkurencji powinna funkcjonować równolegle na gruncie prawa karnego i administracyjnego. W ocenie autorek środki karne powinny być stosowane jako ostateczne środki prawne, w szczególności w sytuacji, gdy zawiodą środki administracyjnoprawne oraz cywilnoprawne.

\section{STRESZCZENIE}

\section{Administratywizacja prawa karnego w sprawach praktyk ograniczających konkurencję}

Przedmiotem analizy w artykule jest problematyka wzajemnych relacji pomiędzy prawem administracyjnym a karnym na przykładzie praktyk ograniczających konkurencję. Autorki zwracają uwagę na wprowadzenie licznych instytucji prawa karnego do postępowania administracyjnego w sprawach praktyk ograniczających konkurencję. W artykule postulowane jest rozszerzenie objęcia kryminalizacją najcięższych naruszeń konkurencji. Ochrona konkurencji na gruncie prawa karnego powinna funkcjonować

57 J. Zimmermann, Prawo, s. 111.

58 Wyrok ETPC z dnia 24 września 1997 r. w sprawie 18996/91 Garyfallou ABBE p. Grecji, www.echr.coe.int. 
równolegle $z$ ochroną uregulowaną w prawie administracyjnym. Regulacje te wzajemnie się uzupełniają.

Słowa kluczowe: kryminalizacja; konkurencja; sankcje

\section{SUMMARY}

The interface between the administrtive law and criminal law in competition-restricting practices

The article analyses mutual relations between the protection of competition under administrative law and under criminal law. The authors draw attention to the introduction of numerous criminal procedural institutions to administrative proceedings regarding restrictive practices. The authors postulate the extension of criminalization of the most serious infringements of competition.

Penal law protection of competition should operate in parallel with the administrative competition law. These regulations complement each other.

Key words: criminalization; competition; sanctions

\section{BIBLIOGRAFIA}

Bernatt M., Tailor-made rules needed: a balance approach to imposition of administrative sanctions in Poland, „Jean Monet Working Paper” 2020, nr 22/14, s. 10-11, https://jeanmonnetprogram.org/wp-content/uploads/2014/12/JMWP22bernatt.pdf.

Bernatt M., Sprawiedliwość proceduralna $w$ postępowaniu przed organem ochrony konkurencji, Warszawa 2011.

Brzezińska-Rawa A., Zakaz nadużycia pozycji dominującej we wspólnotowym i polskim prawie antymonopolowym, Toruń 2009.

Brzezińska-Rawa A., Dyskryminacja jako przejaw nadużycia pozycji dominującej $w$ unijnym prawie konkurencji, „Państwo i Prawo” 2011, R. 66, z. 1 .

Brzezińska-Rawa A., Nadużycie pozycji dominujacej w postaci stosowania ceny nadmiernie wygórowanej, „Przegląd Prawa Publicznego” 2011, nr 1.

Brzezińska-Rawa A., Przesłanki oceny dyskryminacji cenowej jako przejawu nadużycia pozycji dominującej, „Przegląd Ustawodawstwa Gospodarczego" 2011, R. 64, nr 8. 
Brzezińska-Rawa A., Ochrona wartości wysoko cenionych $w$ działalności gospodarczej, w: Węzłowe problemy oddziaływania państwa na konkurencyjność $i$ innowacyjność gospodarki $z$ perspektywy różnych dziedzin prawa, red. A. Brzezińska-Rawa, D. Sylwestrzak, Toruń 2015.

Brzezińska-Rawa A., Sylwestrzak D., Settlement $w$ postępowaniach w sprawach praktyk ograniczajacych konkurencję - instytucja skutecznej ochrony konkurencji czy narzędzie ułatwiające działalność organu antymonopolowego?, w: 25 lat fundamentów wolności działalności gospodarczej. Tendencje rozwojowe, red. J. Grabowski, K. Pokryszka, A. Hołda-Wydrzyńska, Katowice 2013.

Brzezińska-Rawa A., Sylwestrzak D., Leniency $w$ sprawach porozumień ograniczających konkurencję $w$ Polsce. Przeszłość, teraźniejszość, przyszłość, w: Dziesięć lat polskich doświadczeń w Unii Europejskiej. Problemy administracyjnoprawne, red. J. Sługocki, t. I, Szczecin 2014.

Brzezińska-Rawa A., Sylwestrzak D., Instytucjonalne uwarunkowania działalności gospodarczej niezależne od rodzaju działalności gospodarczej, w: Rola państwa $w$ procesach podnoszenia konkurencyjności i innowacyjności przedsiębiorstw. Diagnoza istniejacych uwarunkowań i barier prawnych, perspektywy rozwoju, red. A. Brzezińska-Rawa, Warszawa 2015.

Brzezińska-Rawa A., Sylwestrzak D., Constitutionally justified limitations of freedom of the economic activity: the case of Poland, „International Journal of Social Science and Humanities Research” 2017, Vol. 5, No. 4.

Brzezińska-Rawa A., Sylwestrzak D., The influence of the "important public interest” clause on the competitiveness of undertakings in Poland, „International Journal of Novel Research in Humanity and Social Sciences” 2017, Vol. 4, No. 6.

Cieślak M., Polskie prawo karne. Zarys systemowego ujęcia, Warszawa 1995.

Danecka D., Konwersja odpowiedzialności karnej $w$ administracyjna $w$ prawie polskim, Warszawa 2018, LEX.

Dolniak-Mądrzycka P., Odpowiedzialność osób zarzadzających przedsiębiorca $w$ świetle nowelizacji ustawy o ochronie konkurencji i konsumentów, „Kwartalnik Krajowej Szkoły Sądownictwa i Prokuratury” 2016, z. 2(22).

Doniec A., Stosowanie kar pieniężnych $w$ unijnym i polskim prawie konkurencji w świetle wymogów ochrony praw człowieka, Warszawa 2016.

Gajda-Durlik M., Dekodyfikacja postępowania administracyjnego, w: Koncepcja systemu prawa administracyjnego, red. J. Zimmermann, Warszawa 2007.

Grześkowiak A., w: Kodeks karny. Komentarz, red. A. Grześkowiak, K. Wiak, Warszawa 2019, Legalis. 
Izdebski H., Elementy teorii i filozofii prawa, Warszawa 2011.

Jendrośka J., Koncepcja sankcji karnej $w$ prawie administracyjnym, w: Zbiór studiów z zakresu nauk administracyjnych, red. Z. Rybicki, M. Gromadzka-Grzegorzewska, M. Wyrzykowski, Wrocław 1978.

Jurkowska-Gomułka A., Publiczne i prywatne egzekwowanie zakazów praktyk ograniczajacych konkurencję, Warszawa 2013.

Korycińska-Rządca P., Odpowiedzialność osoby fizycznej w związku z zawarciem przez przedsiębiorcę porozumienia przetargowego $w$ prawie ochrony konkurencji $i$ w prawie karnym, „Internetowy Kwartalnik Antymonopolowy i Regulacyjny" 2017, nr 1(6).

Kasztelan-Świetlik B., Nowelizacja ustawy antymonopolowej. Wystapienie Wiceprezes UOKiK, Bernadety Kasztelan-Świetlik, „Internetowy Kwartalnik Antymonopolowy i Regulacyjny” 2015, nr 2 (4).

Kmieciak Z., Postępowanie $w$ sprawach ochrony konkurencji a koncepcja procedury hybrydowej, „Państwo i Prawo” 2002, nr 4.

Kohutek K., w: Ustawa o ochronie konkurencji i konsumentów. Komentarz, K. Kohutek, M. Sieradzka, wyd. 2, Warszawa 2014.

Król-Bogomilska M., Kary pieniężne $w$ prawie antymonopolowym ( $w$ ustawie o ochronie konkurencji i konsumentów, $w$ europejskim prawie wspólnotowym), Warszawa 2001.

Król-Bogomilska M., Zwalczanie karteli a prawo do rzetelnego procesu i prawo do prywatności - sporne zagadnienia, w: Prawo konkurencji. 25 lat, red. T. Skoczny, Warszawa 2015, LEX.

Król-Bogomilska M., Zwalczanie karteli $w$ prawie antymonopolowym $i$ karnym, Warszawa 2013.

Królikowski M., Zawłocki R., Kodeks karny. Część ogólna. Tom I. Komentarz do art. 1-31, wyd. 2, Warszawa 2011, Legalis.

Kulesza J., Problemy teorii kryminalizacji. Studium z zakresu prawa karnego i konstytucyjnego, Łódź 2017.

Lang, W., Struktura odpowiedzialności prawnej (Studium analityczne z dziedziny teorii prawa), „Zeszyty Naukowe Uniwersytetu Mikołaja Kopernika w Toruniu. Nauki Humanistyczno-Społeczne” 1968, nr 31, s. 36-38.

Longchamps F., Problemy pogranicza prawa administracyjnego, „Studia Prawnicze” 1967, z. 16.

Materna M., Zawłocka-Turno A., Materialne i procesowe zmiany $w$ zakresie praktyk ograniczajacych konkurencję i naruszajacych zbiorowe interesy konsumentów, „Internetowy Kwartalnik Antymonopolowy i Regulacyjny” 2015, nr 2(4).

Materna G., Zmowy przetargowe $w$ prawie ochrony konkurencji i prawie karnym, Warszawa 2016.

Maziarz A., Kilka uwag do projektu nowelizacji ustawy o ochronie konku- 
rencji i konsumentów, „Internetowy Kwartalnik Antymonopolowy i Regulacyjny" 2013, nr 7(2).

Modzelewska de Raad M., System kar pieniężnych $w$ polskiej ustawie o ochronie konkurencji i konsumentów - potrzeba i kierunek dalszych zmian, „Internetowy Kwartalnik Antymonopolowy i Regulacyjny” 2015, nr 2(4).

Molski R. w: Ustawa o ochronie konkurencji i konsumentów. Komentarz, red. T. Skoczny, Warszawa 2014, s. 1402.

Namysłowska M., w: Ustawa o zmianie ustawy o ochronie konkurencji i konsumentów z 5.8.2015 r. Komentarz, red. M. Namysłowska, A. Piszcz, Warszawa 2016, Legalis.

Nowicki D. K., Peszkowski S., Kilka uwag o szczególnym charakterze administracyjnych kar pieniężnych, w: Administracyjne kary pieniężne $w$ demokratycznym państwie prawa, red. M. Błachucki, Warszawa 2015.

Oczkowski T., Komentarz do art. 30 rozporzadzenia UE Nr 596/2014 w sprawie nadużyć na rynku, w: Rozporzadzenie UE Nr 596/2014 w sprawie nadużyć na rynku. Prawo rynku kapitałowego. Komentarz, red. M. Wierzbowski, Warszawa 2016, Legalis.

Oczkowski T., Delikty administracyjne jako szczególna forma represji publicznej. Próba określenia przyczyn coraz większego znaczenia sankcji administracyjnych, w: Teoretyczne i praktyczne problemy wspótczesnego prawa karnego. Materiały z konferencji naukowej. Lublin, 26-27 września 2011, red. T. Bojarski, A. Michalska-Warias, I. Nowikowski K. Nazar-Gutowska, J. Piórkowska-Flieger, D. Firkowski, Lublin 2011.

Piszcz A., Sankcje $w$ polskim prawie antymonopolowym, Białystok 2013.

Piszcz A., „Osoba zarzadzająca” w rządowym projekcie ustawy zmieniajacej ustawę o ochronie konkurencji i konsumentów, „Internetowy Kwartalnik Antymonopolowy i Regulacyjny" 2013, $\mathrm{nr}$ 7(3).

Piszcz A., w: Ustawa o ochronie konkurencji i konsumentów, Komentarz, red. T. Skoczny, Warszawa 2014.

Piszcz A., Nowe elementy regulacji prawnej kar pieniężnych $w$ ustawie o ochronie konkurencji i konsumentów, „Internetowy Kwartalnik Antymonopolowy i Regulacyjny" 2015, nr 2(4).

Radecki W., Kilka uwag o zastępowaniu odpowiedzialności karnej odpowiedzialnością administracyjna, w: Wspótczesne problemy nauk penalnych, „Acta Universitatis Wratislaviensis” nr 1663, Wrocław 1994, s. 13-22.

Róziewicz-Ładoń K., Postępowanie przed Prezesem Urzędu Ochrony Konkurencji i Konsumentów $w$ zakresie przeciwdziałania praktykom ograniczajacym konkurencję, Warszawa 2011.

Sachajko M., Istota i charakter prawny antymonopolowych kar pieniężnych, „Ruch Prawniczy, Ekonomiczny i Społeczny” 2002, R. LXVI, z. 1. 
Stahl M., Sankcje administracyjne - problemy węzłowe, w: Sankcje administracyjne. Blaski i cienie, red. M. Stahl, R. Lewicka, M. Lewicki, Warszawa 2011.

Staniszewska L., Kodyfikacja administracyjnej kary pieniężnej jako instrumentu prawnego na styku z odpowiedzialnościa karna, w: Prawo administracyjne dziś i jutro, red. J. Lang, M. Wierzbowski, Warszawa 2018.

Sylwestrzak D., Postępowanie przed Prezesem Urzędu Ochrony Konkurencji i Konsumentów, „Przegląd Ustawodawstwa Gospodarczego” 2002, R. 55, nr 9.

Sylwestrzak D., Postępowanie przed Prezesem Urzędu Ochrony Konkurencji i Konsumentów, Warszawa 2012.

Syp S., O odpowiedzialności osób fizycznych $w$ polskim prawie konkurencjide lege lata i de lege ferenda, „Internetowy Kwartalnik Antymonopolowy i Regulacyjny" 2012, nr 4(1).

Szumiło-Kulczycka D., Prawo administracyjno-karne, Kraków 2004.

Whelan P., The criminalisation of European cartel enforcement: theoretical, legal and practical challenges, Oxford, 2014.

Wincenciak M., Sankcje $w$ prawie administracyjnym i procedura ich wymierzania, Warszawa 2008, LEX.

Wincenciak M., Przesłanki wyłaczające wymierzenie sankcji administracyjnej, w: Sankcje administracyjne. Blaski i cienie, red. M. Stahl, R. Lewicka, M. Lewicki, Warszawa 2011.

Wolski D., Uwagi dotyczace wybranych instytucji $w$ projekcie nowelizacji ustawy o ochronie konkurencji i konsumentów, „Internetowy Kwartalnik Antymonopolowy i Regulacyjny" 2013, nr 7 (2).

Wróbel A., Odpowiedzialność administracyjna $w$ orzecznictwie Trybunału Konstytucyjnego (na przykładzie administracyjnych kar pieniężnych), red. A. Wróbel, „Europejski Przegląd Sądowy” 2014, nr 9.

Wyrzykowski M., Ziółkowski M., Konstytucyjny status proceduralny jednostki jako adresata działań organów administracji, w: Konstytucyjne podstawy funkcjonowania administracji publicznej. System prawa administracyjnego, red. R. Hauser, Z. Niewiadomski, A. Wróbel, t. 2, Warszawa 2012.

Zimmermann J., Aksjomaty prawa administracyjnego, Warszawa 2013, LEX.

Zimmermann J., Prawo administracyjne, Warszawa 2018. 